\title{
Biofertilizers Application to Improve Growth of Maize and Soil Nutrients
}

\author{
Betty Natalie Fitriatin ${ }^{1, *}$, Muhammad Iqbal Maulana Yusuf $^{2}$, Emma Trinurani Sofyan ${ }^{1}$, and \\ Anne Nurbaity ${ }^{1}$ \\ ${ }^{1}$ Department of Soil Sciences and Land Resouces Management, Agriculture Faculty, Universitas \\ Padjadjaran - Jatinangor 45363-West Java - Indonesia \\ ${ }^{2}$ Agrotechnology, Agriculture Faculty, Universitas Padjadjaran-Jatinangor 45363-West Java - \\ Indonesia
}

\begin{abstract}
Conventional productivity improvement still relies on the use of inorganic fertilizers. The continuous use of inorganic fertilizers is not effective in supporting the improvement of soil health; therefore it is necessary to use environmentally friendly fertilizers such as bio fertilizers. A pot experiment was carried out to study the effect of bio fertilizers application method on growth of maize and soil nutrient $\left(\mathrm{N}_{\text {total }}\right.$ and $\mathrm{P}$ available). Randomized block design was used with nine treatments repeated three times. Liquid bio fertilizers based mollases consist of nitrogen fixing bacteria (Azotobacter chroococcum and Azospirillum) and phosphate solubilizing bacteria (Pseudomonas malei and Bacillus subtillis). The treatments consisted of control, application of biofertilizers to seed (seed treatment) at a dose of $500 \mathrm{ml} \mathrm{ha}^{-1}$ and $250 \mathrm{ml} \mathrm{ha}^{-1}$, application to the soil (soil application with a dose of $5 \mathrm{~L}$ and $2.5 \mathrm{~L} \mathrm{ha}^{-1}$, and combinations of seed and soil application. The results showed that application of biofertilizer increased soil nitrogen $\left(\mathrm{N}_{\text {total }}\right)$, P-available and growth of maize. The combinations of seed and soil application gave a better effect than seed treatment or soil application. Seed treatment $250 \mathrm{ml}$ $\mathrm{ha}^{-1}+$ soil application $2,5 \mathrm{~L} \mathrm{ha}^{-1}$ increased soil nitrogen by $127.2 \%$ and Pavailable by $42.2 \%$.
\end{abstract}

\section{Introduction}

Corn production can be increased with safe and environmentally friendly technology, one of which is the use of bio fertilizers. The indigenous soil microbes consist of bacteria that can dissolve phosphorus and fixed nitrogen, as well as contribute macro nutrients and decompose organic matter [1]. Bio fertilizers are substances that contain live microorganisms that colonize the rhizosphere or the inside of plants and stimulate plant growth by increasing the supply of primary nutrient availability and/or stimulating target plant growth, when applied to seeds, plant surfaces, or soil [2].

* Corresponding author: betty.natalie@unpad.ac.id 
In an effort to increase crop yields, the continuous use of chemical fertilizers in the long term without being balanced with the use of organic matter will face serious obstacles and have an impact on soil damage. An alternative solution to this problem is the use of environmentally friendly fertilizers such as bio fertilizers to help increase soil fertility and provide nutrients that are not available to plants [3].

Utilization of bio fertilizers is carried out based on a positive response to increasing the efficiency of fertilization so that it can save fertilizer costs and use of labor. In this case, the supply of some of the nutrients needed by plants can be carried out by rhizobacteria which have the ability to fix $\mathrm{N}$ from the air and phosphate solubilizing microbes that can convert $\mathrm{P}$ fixed in the soil into P-available for plant growth, thus saving the use of chemical fertilizers [4].

Bio fertilizers can improve fertilization efficiency, fertility and soil health. Bacteria in the rhizosphere environment play an important role in increasing available nutrients and can maintain the macronutrient $\mathrm{N}$ cycle. Inoculation of bio fertilizers consisting of nitrogenfixing bacteria can be one solution to increase the population of nitrogen-fixing bacteria in the rhizosphere environment which is expected to increase soil nutrients [5]. The use of bio fertilizers will not leave residues on crop yields so that they are safe for human health and the environment.

Several researchers have reported that bio fertilizers application increase plant growth and yield. The phosphate solubilizing bacteria increased phosphatase activity, plant growth and yield of maize [6]. Some bacteria from the species Bacilus megaterium, B. subtilis, and Pseudomonas corrugata can increase rice growth because it improves absorption of phosphate fertilizer and increases grain yield [7].

The method of application of bio fertilizers can be done by application of seeds (seed treatment), applied to the soil (soil application) and a combination that will be related to the success of bacterial colonization on host plants. Application of bio fertilizers to seeds is an efficient mechanism for placement of inoculant into soil where they can improve to colonise seedling roots into soil [8]. Therefore, the purpose of this study is to determine the best application method to improve growth of maize and soil nutrient.

\section{Materials and Method}

The pot experiment was conducted at field experiment of Agriculture Faculty Universitas Padjadjaran, Jatinangor, Sumedang District, West Java-Indonsia from August to November 2020. The soil that has been used is the order Ultisols from Jatinangor. The soil has limiting factors including slightly acidic $\mathrm{pH}$ ( $\mathrm{pH}$ 6.48), low C-organic (1.89\%), low-medium content of $\mathrm{N}, \mathrm{P}$, and $\mathrm{K}$ nutrients.

The liquid bio fertilizers containing a consortium of $\mathrm{N}$ fixing bacteria (Azotobacter chroococcum, and Azospirillum) and P solubilizing bacteria (Pseudomonas malei and Bacillus subtillis) in molasses as carrier. The inorganic fertilizers given were Urea $(225 \mathrm{~kg}$ $\left.\mathrm{ha}^{-1}\right)$, super phosphate $\left(112.5 \mathrm{~kg} \mathrm{ha}^{-1}\right)$ and $\mathrm{KCl}\left(37.5 \mathrm{~kg} \mathrm{ha}^{-1}\right)$.

The treatments consisted of control, application of biofertilizers to seed (seed treatment) at a dose of $500 \mathrm{ml} \mathrm{ha}^{-1}$ and $250 \mathrm{ml} \mathrm{ha}^{-1}$, application to the soil (soil application with a dose of $5 \mathrm{~L}$ and $2.5 \mathrm{~L} \mathrm{ha}^{-1}$, and combinations of seed and soil application. The application of biofertilizers was carried out by two techniques were application to seeds and to soil. Application of biofertilizers on seeds was done by mixed with a little water and gum arabic. Application of biofertilizer to the soil by spraying it on the planting hole in the experimental pot at the time of planting maize.

The parameters were observed growth of maize, soil $\mathrm{N}_{\text {total }}$ (using the Kjeldhal method) and P-available (Bray reagent) that measured at the end of vegetative period. Data were 
collected to analysis of variance (ANOVA) and treatment means were compared using Duncan's Multiple Range Test at $\mathrm{p}=0.05$ probability.

\section{Results and Discusscion}

The application of biofertilizers increased soil $\mathrm{P}$ available and soil nitrogen. The statistical analysis showed that the application technic of biofertilizer increased soil $\mathrm{P}$ available and soil nitrogen significantly (Table 1). This showed that the application of biofertilizers containing $\mathrm{N}$-fixing bacteria and $\mathrm{P}$ solubilizing bacteria increased the soil $\mathrm{N}$ content of the soil and the availability of $\mathrm{P}$ in the soil. These results are in line with research Li et al. [9] stated that inoculation of P-solubility and $\mathrm{N}$-fixing bacteria was able to increase plant biomass, total soil $\mathrm{N}$, nitrogenase activity and increase soil available $\mathrm{P}$. Inoculation of $\mathrm{P}$ solubilizing bacteria was also able to increase the population of PSB in the soil so as to increase $\mathrm{P}$ solubility. There was a positive correlation between the growth of $\mathrm{P}$ solubilizing bacteria and $\mathrm{P}$ solubilization [10].

Table 1 shows that combination of seed treatment and soil application of biofertilizers get better increased on soil nitrogen and $\mathrm{P}$ available than only seed treatment or soil application. Seed treatment $250 \mathrm{ml} \mathrm{ha}^{-1}+$ soil application $2.5 \mathrm{~L} \mathrm{ha}^{-1}$ increased soil nitrogen by $127.2 \%$ and P-available by $42.2 \%$.

Table 1. Effect of bio fertilizers application technique on P-available and N-Total

\begin{tabular}{|l|c|c|}
\hline \multicolumn{1}{|c|}{ Treatments } & P-available $(\mathrm{ppm})$ & N-total $(\%)$ \\
\hline control & $14.00 \mathrm{a}$ & $0.22 \mathrm{a}$ \\
\hline Seed treatment $\left(500 \mathrm{ml} \mathrm{ha}^{-1}\right)$ & $17.77 \mathrm{~cd}$ & $0.40 \mathrm{c}$ \\
\hline Seed treatment $\left(250 \mathrm{ml} \mathrm{ha}^{-1}\right)$ & $17.20 \mathrm{bc}$ & $0.39 \mathrm{bc}$ \\
\hline Soil Application $\left(5 \mathrm{~L} \mathrm{ha}^{-1}\right)$ & $19.57 \mathrm{de}$ & $0.40 \mathrm{bc}$ \\
\hline Soil Application $\left(2.5 \mathrm{~L} \mathrm{ha}^{-1}\right)$ & $15.34 \mathrm{ab}$ & $0.36 \mathrm{~b}$ \\
\hline Seed treatment $\left(500 \mathrm{ml} \mathrm{ha}^{-1}\right)+$ soil application $\left(2.5 \mathrm{~L} \mathrm{ha}^{-1}\right)$ & $17.77 \mathrm{~cd}$ & $0.42 \mathrm{c}$ \\
\hline Seed treatment $\left(250 \mathrm{ml} \mathrm{ha}^{-1}\right)+$ soil application $\left(5 \mathrm{~L} \mathrm{ha}^{-1}\right)$ & $17.10 \mathrm{bc}$ & $0.41 \mathrm{c}$ \\
\hline Seed treatment $\left(500 \mathrm{ml} \mathrm{ha}^{-1}\right)+$ soil application $\left(5 \mathrm{~L} \mathrm{ha}^{-1}\right)$ & $19.23 \mathrm{de}$ & $0.41 \mathrm{c}$ \\
\hline Seed treatment $\left(250 \mathrm{ml} \mathrm{ha}^{-1}\right)+$ soil application $\left(2.5 \mathrm{~L} \mathrm{ha}^{-1}\right)$ & $19.97 \mathrm{e}$ & $0.50 \mathrm{~d}$ \\
\hline
\end{tabular}

Remarks: The average score followed by the same letter is not significantly different according to the

Duncan Test at the 5\% level

The influence of bio fertilizers application technique on the diverse growth parameters of maize was presented in Table (2). The plant growths were measured at eight weeks after planting. Table (2) also shows that the biofertilizers application technic significantly increased plant height, stem diameter and leaf number. Increasing of plant growth is caused by microbial activity contained in biofertilizers. In this study, N-fixing bacteria (Azotobacter chroococcum and Azospirillum) and phosphate solubilizing bacteria (Pseudomonas malei and Bacillus subtillis) were able to grow optimally to facilitate an increase in soil nutrient content, especially nitrogen and phosphorus so that they can support plant growth. This is supported by the research of Dal Cortivo [11] that the diazotrophic bacteria (i.e., Azoarcus, Azospirillum, Azorhizobium) improved plant nitrogen nutrition and root growth.

Measurement of stem diameter was carried out to determine the response to the use of bio fertilizers, application methods to seeds, soil applications and their combination. The results of observations of stem diameter showed that there was a difference between maize without biological fertilizer and maize given bio fertilizer. The combination of seed treatment $500 \mathrm{ml} \mathrm{ha}^{-1}+$ soil application $5 \mathrm{~L} \mathrm{ha}^{-1}$ has the highest stem diameter by $4.10 \mathrm{~cm}$. This is presumably because the accumulation of photosynthate also flows into the shoot, 
which makes the plant stems bigger and not easy to fall. The application of biofertilizers can increase the $\mathrm{N}$ and $\mathrm{P}$ content which causes plants to grow well [12].

Table 2. Effect of biofertilizers application technique on growth of maize at 8 weeks after planting

\begin{tabular}{|l|r|r|r|}
\hline \multicolumn{1}{|c|}{ Treatments } & $\begin{array}{c}\text { Plant height } \\
(\mathrm{cm})\end{array}$ & $\begin{array}{c}\text { Stem diameter } \\
(\mathrm{cm})\end{array}$ & $\begin{array}{c}\text { Leaf number }(\mathrm{per} \\
\text { plant })\end{array}$ \\
\hline Control & $157.00 \mathrm{ab}$ & $3.70 \mathrm{a}$ & $12.50 \mathrm{ab}$ \\
\hline Seed treatment $\left(500 \mathrm{ml} \mathrm{ha}^{-1}\right)$ & $157.50 \mathrm{abc}$ & $3.85 \mathrm{a}$ & $12.50 \mathrm{ab}$ \\
\hline Seed treatment $\left(250 \mathrm{ml} \mathrm{ha}^{-1}\right)$ & $147.00 \mathrm{ab}$ & $3.90 \mathrm{a}$ & $13.00 \mathrm{bc}$ \\
\hline Soil Application $\left(5 \mathrm{~L} \mathrm{ha}^{-1}\right)$ & $140.00 \mathrm{abc}$ & $3.60 \mathrm{a}$ & $12.50 \mathrm{ab}$ \\
\hline Soil Application $\left(2.5 \mathrm{~L} \mathrm{ha}^{-1}\right)$ & $142.50 \mathrm{a}$ & $3.95 \mathrm{a}$ & $12.00 \mathrm{a}$ \\
\hline $\begin{array}{l}\text { Seed treatment }\left(500 \mathrm{ml} \mathrm{ha}^{-1}\right)+\text { soil } \\
\text { application }\left(2.5 \mathrm{~L} \mathrm{ha}^{-1}\right)\end{array}$ & $143.00 \mathrm{a}$ & $3.95 \mathrm{a}$ & $12.00 \mathrm{a}$ \\
\hline $\begin{array}{l}\text { Seed treatment }\left(250 \mathrm{ml} \mathrm{ha}^{-1}\right)+\text { soil } \\
\text { application }\left(5 \mathrm{~L} \mathrm{ha}^{-1}\right)\end{array}$ & $168.75 \mathrm{c}$ & $3.90 \mathrm{a}$ & $13.00 \mathrm{bc}$ \\
\hline $\begin{array}{l}\text { Seed treatment }\left(500 \mathrm{ml} \mathrm{ha}^{-1}\right)+\text { soil } \\
\text { application }\left(5 \mathrm{~L} \mathrm{ha}^{-1}\right)\end{array}$ & $168.00 \mathrm{c}$ & $3.10 \mathrm{a}$ & $13.50 \mathrm{c}$ \\
\hline $\begin{array}{l}\text { Seed treatment }\left(250 \mathrm{ml} \mathrm{ha}^{-1}\right)+\text { soil } \\
\text { application }\left(2.5 \mathrm{~L} \mathrm{ha}^{-1}\right)\end{array}$ & & $3.70 \mathrm{a}$ & $13.50 \mathrm{c}$ \\
\hline
\end{tabular}

Remarks: The average score followed by the same letter is not significantly different according to the

Duncan Test at the 5\% level

The combination of seed treatment and soil application of biofetilizer get better increased on growth of maize than only seed treatment or soil application. Seed treatment $250 \mathrm{ml} \mathrm{ha}^{-1}+$ soil application $2.5 \mathrm{~L} \mathrm{ha}^{-1}$ increased plant height by $14.2 \%$ and leaf number by $3.8 \%$ when compared to seed treatment $250 \mathrm{ml} \mathrm{ha}^{-1}$ without combination of soil application. This study showed that beneficial soil microbes in this case $\mathrm{N}$-fixing bacteria and phosphate solubilizing bacteria were important role to promote plant growth and yield [13]. The microbial inoculants are an alternative to reduce the use of chemical fertilizers. In addition, microbial inoculants pose no environmental hazard and maintain soil health. Azotobacter as bacteria fix $\mathrm{N}$ from the atmosphere which is then fixed in the soil and also releases phytohormones in the root area of plants that can increase plant growth and yield [14].

\section{Conclusions}

Based on this study, it can be concluded biofertilizer application techniques affect the performance of microbes to facilitate the availability of nutrients in the soil. The application of bio fertilizer increased soil nitrogen $\left(\mathrm{N}_{\text {total }}\right)$, P-available and growth of maize. The combinations of seed and soil application gave a better effect than seed treatment or soil application. Seed treatment $250 \mathrm{ml} \mathrm{ha}^{-1}+$ soil application $2.5 \mathrm{~L} \mathrm{ha}^{-1}$ is the best application for increasing maize growth and soil nutrient.

Acknowledgements. This research was supported by grants received (applied research: 1827/UN6.3.1/LT/2020) from the Directorate General of Higher Education Ministry of Research and Technology Indonesia. We thank to Fardian Khairul Hakim for his assistance.

\section{References}

1. Rashid, M., S. Khalil, N. Ayub, S, Alam, \& F. Latif. Pak. J. Biol. Sci. 7 (2): 187 196 (2004) 
2. Basu, A., P. Prasad, S.N. Das, S. Kalam, R,Z. Sayyed, M.S. Reddy, and H.E. Enshasy. Sustainability. 13, 1140. https://doi.org/10.3390/su13031140 (2021)

3. Nosheen, S., I. Ajmal, \& Y. Song. Sustainability. 13, 1868. https://doi.org /10.3390/su13041868. (2021)

4. Kalayu, G. Int. J. Agron. Article 4917256: https://doi.org/10.1155/ 2019/4917256. (2019)

5. Fasusi, O.A., C. Cruz, \& O.O. Babalola. Agriculture. 11(163) : https://doi.org/ 10.3390/agriculture11020163 (2021)

6. Hussain, M.I., H.N. Asghar, \& M.J. Akhtar. Plant Soil and Environment 32(1):71-78 (2016)

7. Trivedi, P., B. Kumar, A. Pandey, \& L.M.S. Palni. Plant Soil Sci. 102:291-299 (2007)

8. Callaghan, M.O. Appl Microbiol Biotechnol. 100 :5729-5746 (2016)

9. Li, Y., Q. Li, \& S. Chen. PeerJ 8:e9062 DOI 10.7717/peerj.9062 (2020)

10. Nosrati, R., P. Owlia, \& M.I. Malboobi. Iran J Microbiol. 6(4) : 285-295 (2014)

11. Dal Cortivo, C., M. Ferrari, G. Visioli, M. Lauro, \& F. Fornasier. Front. Plant Sci., https://doi.org/10.3389/fpls.2020.00072 (2020)

12. Berger, L.R., N.P. Stamford, C.E.R.S. Santos, A.D.S. Freitas, L.O. Franco, T.C.M. Stamford. J. Soil Sci. Plant Nutr., 13 (3), 592-603 (2013)

13. Janati, W., B. Benmrid, W. Elhaissoufi, Y. Zeroual, J. Nasielski \& A. Bargaz. Front. Agron.3. Article 637196 (2021)

14. Sumbul, A., R.A. Ansari, R. Rizvi, \& I. Mahmood. Saudi J. Biol. Sci. 17: 3634-3640 (2020) 